BOZZAY RÉKA

\title{
Debreceni diákok hollandiai egyetemjárása a kora újkorban
}

1622 öszén Tilly csapati feldúlták Heidelberget, ${ }^{1}$ azt a várost és egyetemet, ahol a 16-17. század fordulóján különösen nagy számban fordultak meg magyarországi protestáns, elsősorban kálvinista diákok. ${ }^{2}$ A város eleste első pillantásra talán katonai-politikai eseménynek tünik, mégis ez a momentum komoly hatással bírt a magyar protestáns peregrináció irányának megváltozására. A hollandiai egyetemek - a 17. század első évtizedeiben Franeker és Leiden - jó szívvel fogadták be a magyar peregrinusokat, nem utolsósorban Szenci Molnár Albert közbenjárásának köszönhetően, aki átélve Heidelberg pusztulását, maga is Hollandiába menekült és barátságot kötött a leideni egyetem vezetöségével, Franekerben pedig Sibrandus Lubbertus (kb. 1555-1625) professzorral, aki 1624-től az egyetem rektori tisztségét is betöltötte. Szenci mindkét város egyetemén igyekezett előkészíteni a magyarok felvételét. ${ }^{3}$ Erőfeszítéseit siker koronázta, hiszen 1623-tól kezdve 1795-ig folyamatosan találunk magyarokat a hollandiai egyetemeken - Franekeren és Leidenen kívül még Utrechtben, Groningenben és Harderwijkben - és illusztris iskolákban - Deventerben és Amszterdamban. A debreceniek hollandiai egyetemjárásának kezdete, a többi magyarországi diákhoz hasonlóan, 1623-ban kezdődött. ${ }^{4}$ Ezt megelözően mindössze hat emberről tudunk csak a holland

\footnotetext{
${ }^{1}$ SZABÓ ANDRÁs: A heidelbergi egyetem levéltárának magyar vonatkozású iratai (15601622). „Nem sülyed az emberiség!” Album Amicorum Szörényi László LX. születésnapjára. Főszerk.: JANKOVICS JÓZSEF. Bp., 2007. 1414.

${ }^{2}$ Erről bővebben: HeltaI, JÁNOS: Die Heidelberger Peregrination calvinistischer Studenten aus Ungarn und Siebenbürgen 1597-1621. Peregrinatio Hungarica. Studenten aus Ungarn an deutschen und österreichischen Hochschulen vom 16. bis zum 20. Jahrhundert. Szerk.: FATA, MÁRTA -KURUCZ, GYÖRGY-SCHINDLING, ANTON. Stuttgart, 2006. 65-68.

${ }^{3}$ EREDICS, PÉTER: Ungarische Studenten und ihre Übersetzungen aus dem Niederländischen ins Ungarische in der Frühen Neuzeit. Frankfurt am Main, 2008. 28-31.

${ }^{4} \mathrm{Az}$ első magyar regisztráció Corvinus Mihálytól származik, aki 1623. január 12-én Leidenbe iratkozott be. RIEU, W. N. DU: Album Studiosorum Academiae Lugduno-Batavae, MDLXXVMDCCCLXXV: accedunt nomina curatorum et professorum per eadem secula's. 'sGravenhage, 1875. (A továbbiakban ALB) 165., Szepsi Korocz Gáspárt és Dobrai Gáti Bálintot 1623. április 23-án Franekerben találjuk. FoCKEMA, ANDREAE S. J. és MEIJER, TH. J.: Album studiosorum Academiae Franekerensis (1585-1811, 1816-1844). Franeker, 1968. (A továbbiakban ASAF I) 2006., ASAF I 2007. Az első két debreceni, Tejfalvi Csiba Márton és Mezőlaki Miklós, 1623. augusztus 27-én két másik diákkal együtt szintén Franekerbe iratkozott be. ASAF I 2050., ASAF I 2051.
} 
egyetemeken, ${ }^{5}$ ám ők nem debreceniek voltak. A hollandiai peregrináció 1623-as tömeges megindulásától kezdve közel kétszáz éven keresztül a debreceniek is igen szép számmal vették ki részüket az egyetemjárásból, Hollandiában a kora újkorban utolsóként beiratkozó magyar diák is történetesen debreceni volt, 1795-ben regisztrált Groningenben Pákozdy Mihály. ${ }^{6}$

Kik voltak a Hollandiában tanult debreceni diákok? A kérdés egyszerünek tűnik, a megválaszolása mégis nehézségbe ütközik. A kora újkori forrásaink sajnos nem biztosítanak mindig pontos adatokat a diákok személyazonosságának megállapításához. Elsődleges forrásaink természetesen a beiratkozási listák, mind Hollandiából, mind itthonról. Ezek a listák sajnos gyakran hiányosak, mivel nem mindenki regisztrált, aki tényleg hallgatója is volt az egyetemnek. Ennek oka, hogy nem minden egyetem rendelkezett az egyetemi polgároknak járó kiváltságokkal. Itt meg kell említenünk az önálló akadémiai bíróság, adómentes sör-, bor- és dohányvásárlás jogának biztosítását az egyetemi polgárok számára, ${ }^{7}$ Harderwijkben ezen kívül még az egyetemi polgárok vámmentesen szállíthattak be a városba és onnan ki árut, illetve ők maguk is vámmentesen utazhattak a városba, valamint a katonák elszállásolása alól is mentességet élveztek. ${ }^{8}$ Ennek következtében Utrechtben a magyarországi diákok nem is érezték szükségét a beiratkozásnak, így az ottani hallgatókat illetően egyéb, elsősorban más egyetemi, városi illetve tartományi forrásokat is be kellett vonni a kutatásba. A többi egyetem esetében is igaz, hogy a szenátus, vagy az egyetemi gondnokok aktái is nagyon sok hasznos információval szolgálnak a diákok kilétére és egyetemi életére vonatkozóan. A beiratkozási listák mellett léteztek ún. jelenléti listák (recensielijst) is, amiket a beiratkozási évet követően minden évben, amíg a diák az egyetemen tartózkodott, alá kellett írnia, csak így maradhatott ugyanis egyetemi polgár és részesülhetett az egyetemi privilégiumokban. Ilyen listák az 1650-es évektől kezdve szinte hiánytalanul megvannak Leidenben ${ }^{9}$ és Harderwijkben, ${ }^{10}$ viszont Groningenben ${ }^{11}$

\footnotetext{
${ }^{5}$ Szilvásújfalvi Anderkó Imre, Felckeman Péter, Listius Ferenc, Uppy Jakab, Rasorius Makkai István, Szilágyi János. BOZZAY RÉKA-LADÁNYI SÁNDOR: Magyarországi diákok holland egyetemeken 1595-1918. Bp., 2007. (Magyarországi diákok egyetemjárása az újkorban, 15. k.). 41., 218.

${ }^{6}$ SzÖGI LÁsZLÓ: Magyarországi diákok svájci és hollandiai egyetemeken 1789-1919. Magyarországi diákok egyetemjárása az újkorban 3. k. Bp., 2000. 1873.

${ }^{7}$ Erről részletesen ld. Leiden: MoLHUYSEN, P.C.: De voorrechten der Leidsche Universiteit. Mededelingen der Koninklijke Academie van Wetenschappen, afdeeling letterkunde. Deel 58. serie B. No. 1, Amsterdam, 1924.; Groningen: VEN, FOSKEA VAN DER: 'Groningse Loskoppen' Academierechtspraak in Groningen. Onderwijs en onderzoek: studie en wetenschap aan de academie van Groningen in de 17 e en 18 e eeuw. Szerk.: HUUSSEN, A. H. JR. Hilversum, 2003. 243.

${ }^{8}$ DUINKERKEN, J.: De plaats van de Gelderse Universiteit in de Harderwijkse samenleving. Het Gelders Athene. Bijdragen tot de geschiedenis van de Gelderse universiteit in Harderwijk (1648-1811). Szerk.: BOTS, J.A.H. et al. Hilversum, 2000. 42-43.

${ }^{9}$ Universiteit Leiden I. Archief van den Senaat A2. 31-167. Recensielijsten (1650-1796).

${ }^{10}$ Harderwijk: Gelders Archief (A továbbiakban GldA) 0013 Academie te Harderwijk, 2.2.2.139. Liber recensorum, examenrooster, 1650-1753.
} 
csak a 18. század néhány évéből ismeretesek. Ezek a listák fontos információval szolgálnak arról is, hogy ki mennyi időt töltött el az egyetemen, kiiratkozás az egyetemekről ugyanis nem volt.

A nyomtatott és a levéltári források alapján 2997 magyarországi diák regisztrációját sikerült megállapítani a kora újkorban, ${ }^{12}$ 1623-tól 1795-ig pedig 2991-et. Ez a szám nem tekinthető véglegesnek, hiszen további források bevonása a kutatásba még tovább növelhetik a létszámadatokat, de a nagyságrendet mégis jól tükrözi. A regisztráció nem a peregrinációban résztvevő diákok összlétszámát jelenti, hanem a beiratkozások összességét. Egy diák gyakran több egyetemen is megfordult, ezeknek a hallgatóknak az aránya az összes regisztráció 30\%-a.

A debreceni forrásaink közül ki kell emelni a 2013-ban napvilágot látott Intézménytörténeti források a Debreceni Református Kollégium Levéltárában címü két kötetes munkát, ${ }^{13}$ melynek diáknévsora és névmutatója nagy segítséget jelentett a diákok azonosításában. Külön meg kell említenünk Bakóczi János adattári gyüjteményét is, mely a föiskolai növendékek névsora mellett rengeteg hasznos adalékot közöl a diákok külföldi tanulmányaira és későbbi élete alakulására vonatkozóan is. ${ }^{14}$ A hollandiai és a debreceni forrásokat összevetve 942 hollandiai regisztrációról lehetett megállapítani, hogy az debrecenitől származik, vagyis az összes beiratkozás majdnem 31,5\%-a. Ez nem kevés szám, tekintve, hogy Debrecen mellett Sárospatak, Pápa és az erdélyi kollégiumok (Nagyvárad a Debreceni Kollégiumba történt beolvadása előtt, a kolozsvári református és unitárius kollégiumok, Gyulafehérvár/Nagyenyed, illetve Marosvásárhely) is küldtek hallgatókat.

A debreceni kollégiumnak országos beiskolázási köre volt, ${ }^{15}$ így nem meglepő, hogy szinte az ország egész területéről kerültek ki peregrinusok, noha 522 esetben semmit sem sikerült megállapítani a Hollandiában járt diákok pontos származási helyéről. Akikről mégis rendelkezünk információval, tudjuk, hogy közöttük voltak Vas, Tolna és Veszprém megyékből származók is, vagy ha kelet felé tekintünk, Marosszékből vagy Háromszékből is, a legtöbben mégis Biharból, azon belül is Debrecenből származtak. ${ }^{16}$ A képet bizonyosan nagyban árnyalná, ha az összes diák származási helyéről megbízhatóbb adataink lennének.

Debreceniek valamennyi hollandiai felsőoktatási intézményben megfordultak, ahova magyar és erdélyi diákok is beiratkoztak. Jól megfigyelhető, hogy az összes beiratkozással összehasonlítva a debreceniek regisztrációja is követi

\footnotetext{
${ }^{11}$ Groningen: Regionaal Historisch Centrum Groninger Archieven (A továbbiakban RGCGA), Toegangnummer 46. Senaat en de faculteit van de Groningse universiteit 2.1.1.3.46. 'Recensielijsten', lijsten van opnieuw ingeschreven studenten, 1765-1807.

${ }^{12}$ BOZZAY-LADÁNYI: i. m. adattár alapján sikerült a létszámot megállapítani.

${ }^{13}$ Intézménytörténeti források a Debreceni Református Kollégium Levéltárában I-II. Szerk. Szabadi István. Debrecen, 2013.

${ }^{14}$ Tiszántúli Református Egyházkerületi és Kollégiumi Levéltár (A továbbiakban TtREKL), II. 28. Bakóczi János adattári gyüjteménye 1536-1980.

${ }^{15}$ BARCSA JÁNOS: A Debreceni Kollégium és partikulái. Debrecen, 1905.

${ }^{16}$ Vas: Öri P. Péter Tolna: Nagy György, Veszprém: Kalmár György, Marosszék: Marosvásárhelyi Szűcs János, Háromszék: Gidófalvi Csulak János, Bihar: Debreceni Balyik János. BOZZAY-LADÁNYI: i. m., 193., 119., 111., 48., 51., 50.
} 
a magyar trendeket, vagyis a legtöbben Franekerben tanulnak (1233-ból 402 debreceni), ezt követi Utrecht (740-böl 287 debreceni), Leidenben 655-böl 137-en debreceniek, Groningenben 283-ból 95-en, Harderwijk és Deventer esetében megfordul a sorrend: Deventerben 27-böl 9, Harderwijkben 38-ból 5 debreceni. Amszterdamban ekkor még csak illusztris iskola müködött, a kora újkorból nincsenek pontos beiratkozási adataink, forrásunk a diákok album amicoruma. Ebböl tudjuk, hogy 22 ott megfordult magyarból 7 volt debreceni. Különösen kiemelném Utrechtet, mivel itt arányaiban nagy a debreceni létszám. Ennek oka lehetett a 18. században az a sokrétü támogatás, amit a város, a tartomány és egy magánszemély alapítványa biztosított. Hasonló financiális oka lehet a leideni alacsony létszámnak, ugyanis a 18. században az egyetem teológusképző kollégiumában, a Staten College-ben csak erdélyiek kaptak ösztöndíjas helyeket, így a pataki és debreceni diákok létszáma igencsak visszaesett.

A tanulmányaikat illetően sem tértek el a debreceniek szakválasztásai a magyar tendenciáktól. Bár 502 esetben nincsen feltüntetve a tanult szak, a legtöbben, 417-en teológiát hallgattak első szakként és második szakként még négyen választották ugyanezt; orvosnak első szakként 11-en, másodikként még hárman tanultak; első helyen filozófiát 9 ember választott, másodikként még 23 diák. Jogot ketten, keleti nyelvet 1 ember tanult. Olyan esetekben, amikor a beiratkozáskor nem tüntették fel a szakot, segíthetnek a disputációk témái a hallgatók tanulmányait illetően. 61 teológiai disputációról tudunk olyan hallgató esetében, akinek hivatalosan nem ismerjük a választott szakját. Öten filozófiából, heten orvostudományból disputáltak, feltételezhetjük, hogy ebben az irányban végezték tanulmányaikat is. ${ }^{17}$

A diákoknak kiutazásuk előtt különféle papírokat kellett beszerezniük és természetesen pénzt kellett gyüjteniük. A külföldi tanulmányokat a Magyar Királyságban a 17. században semmiféle törvény nem szabályozta, egyedül 1609ből ismerünk egy törvényt, mely olyan személyekre vonatkozott, akik haszonból vagy zsoldért utaztak külföldre, nekik kiutazásuk előtt királyi engedélyre volt szükségük. ${ }^{18}$

A Rákóczi-szabadságharc idején debreceni és pataki diákok útlevelet és gyakran pénzt is kaptak a fejedelemtől. ${ }^{19}$ A szabadságharc leverése után Magyarországon is azok a szabályozások voltak érvényesek, melyek Erdélyben is a diákok kiutazását befolyásolták: így 1725-től útlevél-kötelezettséget vezettek be, mely a debreceni diákokat is érintette. ${ }^{20}$

A Hollandiában megfordult debreceni diákok többsége teológiát tanult, ezért félő volt, hogy a hollandiai kálvini egyházban megjelenő, a Magyarországon elfogadott ortodoxiától eltérő újítások a Tiszántúlra is megtalálják az utat a diákokon

\footnotetext{
${ }^{17} \mathrm{Az}$ adatok a BOZZAY-LADÁNYI adattárból származnak.

${ }^{18}$ KLEIN GÁSPÁR: Az állami protestáns egyetem eszméje a Habsburgok alatt a XVIII. és XIX. században. Debrecen, 1930. 360-361.

${ }^{19}$ LADÁNYI SÁNDOR: A sárospataki és debreceni kollégium a Rákóczi-korban. Rákóczitanulmányok. Szerk.: R. VÁRKONYI ÁGNES, KÖPECZI BÉLA, HOPP LAJOS. Bp., 1980. 339-341.

${ }^{20}$ SZABÓ MIKLÓs: Erdélyi diákok külföldi egyetemjárása a XVI-XVIII. században. Müvelödéstörténeti tanulmányok. Szerk. CSETRI ELEK, JAKó ZSIGMOND, SiPOS GÁBOR, TONK SÁNDOR. Bukarest, 1980. 162.
} 
keresztül. A külföldi akadémiákról hazatérőket ezért vizsgálatnak vetették alá, a bünösöket kiközösítették. ${ }^{21}$

Az egyik legsúlyosabb vád, amivel a Hollandiából, elsősorban Leidenből hazatérö diákokat illethették, az arminianizmus vádja volt. Jacobus Arminius (15601609) leideni professzor követöit az 1618-as dordrechti zsinaton felmentették hivatalukból, egyetemi állás betöltésére pedig alkalmatlannak nyilvánították őket. ${ }^{22}$ Mégis igen sok követőre találhattak nézetei a magyarok között is, mivel a 1631-ben a nyírbátori zsinat is foglalkozott az arminianizmus kérdésével. ${ }^{23}$ A Tiszántúli Református Egyházkerületi és Kollégiumi Levéltárban őrzik azt a formulát, melyet magyar diákok írtak alá, mielőtt külföldre utaztak volna, ebben tettek ígéretet arra, hogy a helvét hitvallással ellenkező mindenféle szektáktól, így az arminianizmustól is távol tartják magukat. ${ }^{24} \mathrm{~A}$ helyzet viszont a szigorú szabályozás ellenére sem változott meg, legalábbis ezt bizonyítják az 1638. szeptember 23-án kelt debreceni zsinati határozatok. $^{25}$

A 18. századtól kezdve főleg a kollégiumok foglalkoztak a diákok peregrinációjával. 1750. január 21-én Debrecenben a professzorok olyan határozatot hoztak, hogy „, a külföldi akadémiákra menendő ifjak itthoni iskolájuk professzoraitól

\footnotetext{
${ }^{21}$ BíRÓ SÁNDOR, BUCSAY MiHÁLY, TÓTH ENDRE, VARGA ZOLTÁN: A magyar református egyház története. Bp., 1949. 29.

${ }^{22}$ SPIJKER, W. VAN 'T - Bruin, C.C. DE- FloriJn, H.-MoERKERKEN, A.-NATZIJL, H.: De Synode van Dordrecht in 1618 en 1619. Den Hertog, 1987. 115.

${ }^{23}$, Ezentúl csak olyanok ajánltatnak a patrónusoknak, akik (...) a helvét hitvallással ellenkezö mindenféle szektáktól, véleményektől pl. arminianismustól óvakodnak" - TóTH SÁMUEL: Adalékok a Tiszántúli Református Egyházkerület történetéhez, Debreczeni Protestáns Lap, 1883, I. 41.

${ }^{24}$ TtREKL I. 1. j. Külföldi akadémiákon tanult diákok iratai D.1. 1634. január 17-én: Vári N. Miklós, Fejérvári Mihály, Tarczali Bogdán Péter, Kismarjai Lukács, Decsi Péter, Marosvasárhelyi Szűcs János, Váczi János, Diószegi István, 1646. július 24-én: Komáromi Szvertán István, Pécsváradi B. Mihály, Szokolyai Anderkó István, Mányoki Sartorius [Szabó] István, Székelyhidi Tofeus Mihály, Szathmári Baka Péter, Lázár Szathmári Miklós, Kecskeméthi Miklós, Debreceni Péter, Vári István, Szecsei B. János, Kisfalvi Tamás, Pankotai Ferenc, Zabola Miklós, Köleséri Mihály, Gönczi Mátyás, Nagyharsányi Jakab, 1649. május 3án: Decsi Gáspár, Újvári István, Enyedi Fazekas János, 1648. május 27-én: Debreceni Hentes Mihály, 1648. május 29-én: Borsai Ferenc, Enyedi Sámuel, Szilágyi Tarpai András, Batizi Csormoly Gáspár, 1651. május 9-én: Szepsi Korocz András, Gidófalvi István, 1655. május 8-án: Pályi Mihály, 1656(?): Debreceni János.

${ }^{25}$ „azon újitások megelözése végett, a melyeket némely Angliában és Hollandiában összeesküdtconspirati - magyar alumnusok akarnak az egyházba behozni. Ezentul a tiszáninneni és tuli akademikusok semmiféle egyházi hivatalba sem bocsáttatnak mindaddig, még visszajövetelök után hitekröl, tudományokról, keresztyéni magaviseletekröl bizonyságot nem tesznek s esküvéssel s nevök adásával nem kötelezik magokat a következő feltételek megtartására.

A kisebb kánonok 5-dik czikke:

A hitágazatokban s a keresztyén vallás más alapjaiban, a szertartásokban, sákramentomokban, s a magyarországi egyházban régóta fenálló rendtartásokban, magánosan, saját tekintélyével sokak botrányára és sérelmére senki változtatást vagy ujitást tenni ne merészeljen, hanem ha valamit megujitandónak tart, az egész egyház megegyezésével nyilvános zsinaton történjék az." - ТóTH, i. m., I., 63 .
} 
bizonyítványt vigyenek", ${ }^{26} \mathrm{~s}$ még ugyanabban az évben az egyházkerületi jegyzőkönyvbe is beírták, hogy az „Académiákra menők, a superintendenstöl és tanároktól bizonyítványt mutassanak fel. Kiknek ilyen és erkölcsi bizonyítványaik nincsenek, nem alkalmazhatók egyházi szolgálatra." ${ }^{27}$ Tíz évvel később ezt a határozatot újból megerősítették. ${ }^{28} \mathrm{~A}$ debreceni professzorok félve attól, hogy diákjaik esetleg külföldön maradnak, 1750-ben Debrecenben a következö határozatot hozták: „az alumnusok kézadással kötelezik magukat, hogy két évet kint töltenek; ha egyik-másikójukat ez idön belül visszaszólítja valamely tisztes hivatal, azt a professzoroknak hírül adják.,"29

A külföldi tanulmányokért súlyos árat kellett fizetni. ${ }^{30}$ A tudásvágy mégis sokakat bírt rá arra, hogy akár még pénzügyi fedezet nélkül is nekivágjon az útnak, és adósságokba keveredjen. Ezért a református egyház 17. századi zsinati határozatai között olvasunk arról, hogy a diákoknak adott pénzt csak tudományos célokra lehetett használni (Nyírbátor, 1631.), ${ }^{31}$ illetve külföldre csak olyanok utazhattak, akiknek pénzük és patrónusuk volt (Feketeardó, 1680.). ${ }^{32}$

Kevesek tudták önerőből fedezni az utazás és a kinti tanulmányok árát, ezért a szükséges pénzt különféle forrásokból kellett előteremteni a peregrinusoknak. Néhány hazai kollégium külön kasszát létesített a költségek fedezésére. Ilyen volt Debrecenben a Bursa Sacra, melyből több Hollandiában is megfordult diák részesült. ${ }^{33}$ Magánszemélyek is támogattak Debrecenben különböző kollégiumi alapokat, melyek diákok külföldi tanulmányait segítették. 1709-ben Szabó Szappanos Istvánné született Kocsi Kata végrendeletében egy csapó utcai ház eladásából származó pénz kamatait és készpénzben nyolcvan forintot adott a kollégiumnak azzal a feltétellel, hogy az összeget külföldön doktori címet szerző diáknak kell adni ${ }^{34}$ 1717-ben Báthori Szabó András 100 magyar forint kamatait hagyta a kollégiumra; ${ }^{35}$ 1723-ban Telekesi Török István özvegye 1000 forint kamatát adta a peregrinációra stb. ${ }^{36}$

Városoktól is lehetett pénzt kapni, Debrecen város tanácsától Medgyesi Pál 200 dukátot, 100 tallért, 100 forintot, ${ }^{37}$ Laskói Lőrinc 50 tallért,, ${ }^{38}$ Tarczali Pál 25

\footnotetext{
${ }^{26}$ TtREKL I. 3. d. Világi urak levelei. Ezt a határozatot 1759. január 17-én tartott egyházkerületi gyülésen újból megerösítették.

${ }^{27}$ TóTH, i. m., II., 29.

${ }^{28}$ Uo., 110.

${ }^{29}$ TtREKL I. 3. d. Világi urak levelei 1731-1895.

${ }^{30}$ RÁCZ IsTVÁn: Az ország iskolája. A Debreceni Református Kollégium gazdasági erőforrásai.

Debrecen, 1995. 235.

${ }^{31}$ TóTH, i. m., I., 29-30.

${ }^{32}$ TóTH, i. m., I., 54-55.

${ }^{33}$ BARÁth BÉLA LEVENTE: Adattár Martonfalvi György peregrinus diákjairól. Debrecen, 2001. (A D. Dr. Harsányi András Alapítvány Kiadványai, 3. k.)

${ }^{34}$ Uo., 253.

${ }^{35}$ BALOGH FERENC: A Debreceni Református Főiskola alapítványi törzskönyve. Debrecen, 1911. 29.

${ }^{36}$ Uo., 305.

${ }^{37}$ Magyar Nemzeti Levéltár Hajdú-Bihar Megyei Levéltára (a továbbiakban MNL HBML), Magisztrátusi jegyzőkönyvek. IV. A. 1011/a. 9. k. 228.
} 
tallért, ${ }^{39}$ Tiszavarsányi Dániel 100 tallért ${ }^{40}$ kapott. Mások közvetlenül magányszemélyektől kaptak pénzt. Szokolyai Anderko István hidvégi Nemes János, illetve Nádudvari K. András pedig Király Anna, Bácsi János és Tiszta János támogatásával utazott külföldre. ${ }^{41}$ Hatvani Istvánról tudjuk, hogy 300 rénes forintot gyüjtött össze Debrecen város tanácsától, a debreceni gyülekezettől és a kollégiumtól még további 200 rénes forintot kapott. ${ }^{42}$ Söt, miután úgy döntött, hogy Svájcból Hollandiába megy folytatni a tanulmányait, Debrecen város tanácsa még 100 rénes forinttal támogatta. Utrechtbe 160 forintot, majd még 40-et küldtek neki, amit Dömjén Gergely ágens utalt el neki, hogy a könyveit kiválthassa. ${ }^{43}$

A hollandiai egyetemek is biztosítottak különféle anyagi támogatást. Az egyik legszélesebb körủ ellátást a leideni Staten College biztosította. Itt eredetileg csak hollandiai teológushallgatók tanultak ${ }^{44}$ majd csak a 17 . század végétől kezdve nyitotta meg kapuit közép-kelet-európai diákok előtt is. 1681-től kezdve két helyet litván, 1700. május 14-től pedig további két helyet kaptak Nagy-Lengyelország és Poroszország egyesült evangélikus egyházának diákjai ${ }^{45}$ 1703-tól már több magyar is megfordult itt, de 1715-től rendszeresen részesültek erdélyiek ösztöndíjban, 1734ig gyulafehérvár/nagyenyedi diákok, majd ettől az évtől kezdve kolozsváriak is kaptak még két helyet. Debrecen 1738. január 20-án próbált a diákjainak helyet szerezni. ${ }^{46}$ Debrecennek a leideni szenátushoz és a rendekhez írt levele után Albertus Schultens professzor még egy emlékeztetőt is összeállított a magyar és erdélyi rendek helyzetéről, melyet 1738. október 21-én és 27-én adott át az egyetemi gondnokoknak, ${ }^{47}$ de a kérésre nem érkezett pozitív válasz. Debrecen 1745. január 11-én megismételte a kérését, de ekkor is elutasító választ kapott. ${ }^{48}$ Mégis volt debreceni diákja a Staten College-nek. Miután 1703-ban Henczidai Mátyás elhagyta a Staten College-t, Johannes Antonius Valesius nevét említik az iratok. Valesius cseh származású volt, Szakolcán született, de 1703. március 24-én a debreceni törvényeket írta alá. ${ }^{49}$ Hat évvel később 1709. június 21-én ${ }^{50}$ Leidenben magyar

\footnotetext{
${ }^{38}$ MNL HBML IV. A. 1011/a. 17. k. 234.

${ }^{39}$ Uo., 302.

${ }^{40}$ Uo., 506.

${ }^{41}$ TtREKL II. 28. c. 1. Föiskolai tanárok névsora 1588-1791.

${ }^{42}$ LÓSY-SCHMIDT EDE: Hatvani István élete és müvei 1718-1786. Debrecen, 1931. 60-61.

${ }^{43}$ Uo., $76-77$.

${ }^{44}$ Ahogyan a hollandoknak, úgy felvételük után a Staten Collegeben tanult magyaroknak is esküt kellett tenniük, hogy csak teológiát hallgatnak. Peregrinuslevelek. 1711-1750. Külföldön tanuló diákok levelei Teleki Sándornak. Adattár XVI-XVIII. századi szellemi mozgalmaink történetéhez, 6. k. Szerk. HofFMANN GizELLA. Szeged, 1980. 99.

${ }^{45}$ MOLHUYSEN, PHILIPP CHRISTIAAN: Bronnen tot de geschiedenis der Leidsche Universiteit. 's-Gravenhage 1913-1924. V. 71-75.

${ }^{46}$ Het Archief van Curatoren van de Leidsche Universiteit (a továbbiakban AC) Net-resolutiën. Nr. 32. 267.

${ }^{47}$ Uo., $659-671$.

${ }^{48}$ AC Bijlagen tot de resolutiën, 1574-1811. Nr. 45. Miután Debrecen megismételte kérését, újabb emlékeztető készült a sárospataki, debreceni és marosvásárhelyi kollégium helyzetéről. Uo. 1745. április. 7.

${ }^{49}$ Intézménytörténeti források..., 366.

${ }^{50} \mathrm{AC}, \mathrm{A} 2$ 680. Acta van het Collegie der Theologie Nr. 680. 633.
} 
ösztöndíjas helyre vették föl, és az akták is gyakran magyarként említik, bár a beiratkozáskor Bohemus-nak nevezte magát. ${ }^{51}$

Harderwijkben a magyar diákok a Fraterhuis-ben kaptak ösztöndíjas helyet. Felvételükről először 1737. május 17-én rendelkeztek a kurátorok aktái. ${ }^{52}$ Az ellátást nyert két magyar diáknak évente 50 guldent biztosítottak. 1739-ig féléves ciklusban fizették a pénzt, majd egy 1739. június 16-án kelt határozat értelmében negyedévenként részesítették a diákokat ösztöndíjban. ${ }^{53} \mathrm{Az}$ ötven guldenes éves támogatást 1743. május 21-én a Nagyenyedi Kollégium kérésére még 25 guldennel megemelték, így az elkövetkező években összesen 75 guldent kaptak a Fraterhuisben lakó magyarok. ${ }^{54}$

Öt debreceniről tudunk Harderwijkben, ebböl hárman voltak a Fraterhuis ösztöndíjasai. A leghosszabb időt Nagykőrösi Úri János töltötte itt, aki már a beiratkozása előtt, 1750. szeptember 1-én ösztöndíjat nyert Harderwijkben, ${ }^{55}$ és a számlák tanúsága szerint egészen 1756. június 9-ig itt tartózkodott. ${ }^{56}$ Balogh Ádám 1757. augusztus 7-én iratkozott be, de számlát a nevére már június 1-tôl állítottak ki 1758. április 10-ig, sőt még $1 / 4$ éves ösztöndíjat, 18 gulden 15 stuivert is kapott Magyarországra való utazására 1758. április 10-én Van Westervelt kurátor tudtával. ${ }^{57}$

Szalai Pál 1790. április 17-én iratkozott be, majd 1790. június 5-én azzal a kéréssel fordult a szenátushoz, hogy tanulmányai folytatásához segítséget kapjon. ${ }^{58}$ Június 9-én a kurátorok, ${ }^{59}$ majd június 22 -én a szenátus is azt a határozatot hozta, hogy Szalainak tanulmányai folytatására egy évre 100 guldent adnak (vagyis negyedévente 25 guldent fizetnek), az első kifizetésre pedig 1790. július 1-jén kerül majd sor, valamint a Fraterhuis-ben lakhat. ${ }^{60}$ Szalai a számlák tanúsága szerint egy évig maradt Harderwijkben és ténylegesen csak 50 guldent fizettek ki neki. ${ }^{61}$

1753. február 27-én szintén szenátusi határozat alapján szerzett ingyen filozófiai doktori címet Nagykőrösi Úri János. ${ }^{62}$ Ugyancsak ő egyébként még kétszer részesült

\footnotetext{
${ }^{51} 1709$. február 26. ALB 809.

${ }^{52}$ GldA 0013 Academie te Harderwijk, 2.1.2.2. Register van besluiten van de curatoren, 1688 oktober-1787, 266.

${ }^{53}$ Uo., 273-274.

${ }^{54} \mathrm{Uo}, 329$.

${ }^{55}$ GldA 0013 Academie te Harderwijk 2.1.3.30. Rekeningen 25-46 van W. ten Holthe, 17281751.

${ }^{56}$ GldA 0013 Academie te Harderwijk 2.1.3.35. Rekeningen 1-26 van R.C.W. de Wolff van Westerrode, 1752/1753-1777/78.

${ }^{57}$ Uo.

${ }^{58}$ GldA 0013 Academie te Harderwijk 2.2.1.56. Besluiten van de Academische Senaat, 1784$1796,333$.

${ }^{59}$ GldA 0013 Academie te Harderwijk, 2.1.2.3. Register van besluiten van de curatoren, 17881799, 54-56.

${ }^{60}$ GldA 0013 Academie te Harderwijk 2.2.1.56. Besluiten van de Academische Senaat, 17841796. 337-338.

${ }^{61}$ GldA 0013 Academie te Harderwijk 2.1.3.38. Rekeningen 1-10, 12-13, 19 en 24-30 van A.P. van Westervelt 1778/79-1807.

${ }^{62}$ GldA 0013 Academie te Harderwijk, 2.2.1.54. Besluiten van de Academische Senaat, 1752-1766. 18.
} 
a kurátorok anyagi támogatásában. Elöször 1753. június 13-án 100 guldent kapott, miután summa cum laude védte meg a filozófiai doktori értekezését, majd 1756. június 9-én 25 gulden egyszeri támogatásban részesült. ${ }^{63}$

Szintén jelentős pénzügyi segítséget jelentett a diákoknak, ha a disputációik kiadását pénzzel támogatta az egyetem. Veszprémi Sámuel 1729. január 29-én 19 gulden 4 stuivert kapott, hogy Cremer professzor elnöklete alatt disputáljon, majd szintén ő részesült 16 gulden és 10 stuiverben Ens professzor elnöklete alatt folytatott disputációjáért 1729. március 21-én. ${ }^{64}$ Néhány hónappal később a kurátorok jóváhagyásával Cremer professzornak fizetett az egyetemi oeconomus 36 guldent, melyből Veszprémi disputációjának költségét kellett fedezni. ${ }^{65}$

Groningenben 1614-ben Groningen város és Ommeland tartomány rendjei döntöttek egy bursa „beneficium mensa publica” - tulajdonképpen a mai menza elődje - felállításáról, mely eredetileg 40 diákot látott el ${ }^{66}$ Ezt a számot 1628-ban 40-röl 60-ra emelték, ahol 30 hazai és 30 idegen (nem a városból és a tartományból származó) is étkezhetett, ${ }^{67}$ majd az alumnusok számát 1673-ban a felére csökkentették. ${ }^{68}$ A bursának megfelelő helyet találtak a Broederskerkhoff-on, ahol az egészen 1813-ig üzemelt. ${ }^{69}$ Alapításakor a bursa nem volt teljesen ingyenes, csak az étkezések költségének felét állták, a következő évek határozatai viszont egyértelmüen bizonyítják, hogy bizonyos számú diák teljesen ingyen étkezhetett (volle burse), míg mások fél áron kaptak ételt (halve burse). 1720. július 22-én a bursában étkezőket három asztalhoz osztották be. Az újonnan érkezetteket a legutolsó asztal legutolsó helyére rakták (itt kapták a legkevesebb támogatást) és innen lehetett feljebb jutni, vagyis több támogatást szerezni az étkezéshez. A diákok ekkor 60 guldent adtak egy évre, de egyszerre csak egy negyedévi étkezési díjat fizettek ki. ${ }^{70}$ Mivel a szabad vagy félszabad asztal használata kiváltságnak számított, csak a legkiválóbbak nyertek erre lehetőséget, az alumnusokra vonatkozó törvények ezért félévenként a bursát látogatók vizsgáztatását írták elő. A vizsgákat egészen 1673-ig rendszeresen meg is tartották, majd újból csak 1790-ben vezették be őket. ${ }^{71}$

\footnotetext{
${ }^{63}$ GldA 0013 Academie te Harderwijk, 2.1.2.2. Register van besluiten van de curatoren, 1688 oktober-1787, 424. és 456.

${ }^{64}$ GldA 0013 Academie te Harderwijk, 2.1.3.32. Bijlagen bij de rekeningen van W. ten Holthe, 1719-1730.

${ }^{65}$ Uo. és GldA 0013 Academie te Harderwijk, 2.1.3.30. Rekeningen 25-46 van W. ten Holthe, $1728-1751$.

${ }^{66}$ Regionaal Historisch Centrum Groninger Archieven (továbbiakban RGCGA), Toegangnummer 47. Curatoren van de Groningse Universiteit, 2.1.3.35. Resolutiën rakende de provinciale burse, register van resolutiën der staten van Stad en Lande en het college van curatoren betreffende de burse, 1615. febr. 28.-1770. april 9.

${ }^{67}$ Uo.

${ }^{68}$ Uo., 1698. április 1.

${ }^{69}$ JonCKBLOET, W. J. A.: Gedenkboek der Hoogeschool te Groningen. Groningen, 1864. 406-407.

${ }^{70}$ RGCGA, Toegangnummer 47. Curatoren van de Groningse Universiteit, 2.1.3.9. „Resolutien der heeren curatoren”, resolutiën van het college van curatoren, 1700. febr. 20 1750. mei 28.

${ }^{71}$ JONCKBLOET, i.m., 414.
} 
További feltétele a szabad asztal használatának, hogy a bursa diákjainak az egyetemi törvények felolvasásakor jelen kellett lenniük, különben elveszítették kiváltságukat. ${ }^{72}$ Gyakran megvádolták a magyarokat, hogy ezt elmulasztották. 1749. október 29-én Török János debreceni diák két másik magyarral maradt távol. ${ }^{73} 1658$ és 1783 között 104 magyarországi diák kapott itt ellátást, ebből 33 volt debreceni. ${ }^{74}$ Már az első bejegyzés is egy debrecenitől származott: Csedregi Péter szükös helyzetéről panaszkodott a rektornak, aki végül a gondnokokkal folytatott tárgyalás után télire megadta a szabad bursa használatot, valamint egy heti pénzt rendelt neki. $^{75}$

Utrechtben 1722-ben született városi határozat ${ }^{76}$ a magyarok anyagi támogatásáról, s először 1723-tól fizették ki a pénzt (300 gulden), ehhez járult még hozzá a tartomány is (450 majd 600 guldennel).$^{77}$ A pénzösszeget minden évben a teológiai kar kérte meg, de nem csak teológusok részesülhettek benne. ${ }^{78}$ A diákok neveit az 1750-es évektöl tüntették fel, többször a beiratkozás vagy az ösztöndíjban való részesülés időpontjával együtt. Utrechtben is több debreceni kapott ösztöndíjat. ${ }^{79}$ Szintén itteni a Stipendium Bernardinum is, melyet 1761-ben

\footnotetext{
${ }^{72}$ RGCGA, Toegangnummer 47. Curatoren van de Groningse Universiteit, 2.1.3.35. Resolutiën rakende de provinciale burse, register van resolutiën der staten van Stad en Lande en het college van curatoren betreffende de burse, 1615. febr. 28.-1770. april 9., itt: 1717. július 23.

${ }^{73}$ Uo.

${ }^{74}$ Csedregi Péter, Sallai Pál, Szilágyi Márton, Szőnyi István, Bölcskei Mihály, Veresmarti Mátyás, Bősházi János, Debreceni K. Benedek, Ráczkevi Márton, Thúri Sebestyén, Öri P. Péter, Gúti András, Negyedi Sámuel, Császári István, Maróthi György, Naszályi István, Liszkai Miklós, Debreceni Király János, Debreceni János, Kalmár János, Patai János, Molnár Ferenc, Habokai Márton, Munkácsi István, Török János Ferenc, Szőnyi G. Mihály, Jenei Ferenc, Vásárhelyi Sámuel, Bojti Pál, Vecsei József, Pálos János, Sinai Miklós, Csernák László. BozZAY RÉKA: Magyar diákok a groningeni bursában. Emlékkönyv Barta János 70. születésnapjára. Szerk.: PAPP IMRE, ANGI JÁNOS, PALLAI LÁSZLÓ. Debrecen, 2010. 131-139.

${ }^{75}$ RGCGA, Toegangnummer 46. Senaat en de faculteit van de Groningse universiteit, 2.1.1.2.16. 'Acta senatus academici', klad-resoluties van de senaat, 1651 aug. 25.-1671 aug. 17.

${ }^{76}$ 1721. május 5. Resolutiën van de Vroedschap van Utrecht betreffende de Academie. Kiad.: MIEDEMA, LUCIE. Utrecht, 1900. 200.

${ }^{77}$ 1720. március 6. Het Utrechts Archief (A továbbiakban HUA), 233 Staten van Utrecht, Tweede serie van de resoluties: 232. Nr. 67.

${ }^{78}$ Két orvosról is tudunk: Borosnyai Pál (HUA 702-1 Stad van Utrecht, Minutenresolutie 123. Nr. 79., 81., 82.), Zoltány József (HUA 702-1 Stad van Utrecht, Minutenresolutie 123. Nr. 71.), akik azonban nem debreceniek voltak.

${ }^{79}$ HUA 702-1 Stad van Utrecht, Minutenresolutie 123. Nr. 54-től 109-ig: 1750-1794 között: Cserei János, Soós Imre, Szalai István, Kádár János, Szilágyi István, Csepeli Ferenc, Bekes János, Veszprémi István, Kolorsányi János, Szentgyörgyi Sámuel, Somodi István, Szappanos Mihály, Farkas István, Polgári Mihály, Farkas István, Nagy Mihály, Tunyogi Mihály, Szikszai György, Bóka Sándor, Csernák László, Dobrai József, Fazekas János, Márialaky Dániel, Kiss Imre, Szondi György, Madas Sámuel, Szőke Mihály, Nagy Mihály, Árvay Pál, Szikszai Benjámin, Mándi József, Debreceni István, Konkoly Tege Mihály, Dömsödi Dániel, Técsi Miklós, Körösi János, Molnár József, Mándi József, Szabó József, Dósa Harcsa János, Ferenczi István, Petredi József, Szanai István, Göde István, Fodor András, Bányai János,
} 
alapítottak, ebböl is részesültek debreceniek. ${ }^{80} \mathrm{Az}$ ösztöndíjasok névlistájának összevetéséből úgy tủnik, hogy egy ember akár több forrásból is számíthatott támogatásra. A franekeri bursában, vagy mensa academicán 1774-ig 10, 15 majd a rendek kérésére 20 ember kapott naponta ebédet és vacsorát. ${ }^{81}$

A diákok jelentős része tanulmányai befejezése után hazatért. A többségük teológiai tanulmányaikból adódóan lelkészként helyezkedett el, néhányan szép karriert futottak be az egyházon belül, akár a legmagasabb tisztségig, a püspöki címig is vihették. ${ }^{82}$ A külföldi képzés nem titkolt szándéka volt a debreceni kollégium tanárainak kinevelése. A kora újkorban valamennyi későbbi professzora megfordult valamelyik hollandiai egyetemen. ${ }^{83} \mathrm{Az}$ orvostanhallgatók közül Herczeg János városi tanácsos lett, Pataki Sámuel lelkészként szolgált, a többiek feltehetőleg maradtak az orvosi hivatás mellett. Hollandiában jelentősebb pályát a debreceni (és a magyarországi) diákok közül csak Csernák László futott be, aki a deventeri illusztris iskolában lett a filozófia és matematika tanára. ${ }^{84}$

Összegzésképpen megállapíthatjuk, hogy a debreceni diákok igen jelentős létszámban vettek részt a hollandiai peregrinációban, hiszen az összes beiratkozás közel egyharmada tőlük származott. Hazai jótevőik, valamint az

Ájler György, Kehi Mihály, Fodor János, Szilágyi János, Löcsö András, Benedek Mihály, Pálffy Ferenc, Nagy Mihály, Vadász Pál, Keresztesi József, Tamássa Ferenc, Szilágyi P. János, Nagy István, Osgyáni Pál, Kenéz Gergely, Kemenszki János, Blasek Mihály, Boros György, Mocsi János, Sápi Sámuel, Péczeli Sámuel, Rétsey János, Galamb Zsigmond, Péczeli József, Szentesi Dániel, Keck Dániel, Fazekas András, Ormos József, Szentmiklósi Timót, Kállay János, Tóth Ferenc, Pethe Ferenc, Sátor János, Szalai István, Tóth Ferenc, Naszályi János, Török András, Szentes Sámuel, Musai János, Kovács József, Bodnár Nátán, Tarczali József, Szilágyi István, Maller Pél, Szathmári Dániel, Bartha György, Körtvélyesi Pálm Szabó Péter, Imre János, Gangol István, Bartha György, Bod Péter, Sári Mihály.

${ }^{80}$ SCHINKELSHOEK, W.M.: Was ist ein Name? Liste der Studenten aus der Pfalz und aus Ungarn, die mit Hilfe des Stipendium Bernardinum in Utrecht studiert haben (1761-1945), PDF, 2011. Bijlage bij academisch proefschrift. A debreceni diákok nevei: Polgári Mihály, Bóka Sándor, Csernák László, Dobrai József, Fazekas János, Márialaky Dániel, Kállai Imre, Dömsödi Dániel, Konkoly Tege Mihály, Dósa Harcsa János, Göde István, Ájler György, Szilágyi P. János, Szentesi Dániel, Kenéz Gergely, Péczeli Sámuel, Rétsey János, Fazekas András, Tóth Ferenc, Pethe Ferenc, Bartha György, Körtvélyesi Pál.

${ }^{81}$ Tiszáninneni Református Egyházkerület Levéltára (a továbbiakban TREL), Sárospatak; A XII/3613. Nr. 100. 1766. júl. 9. A bursáról bővebben lásd: POSTMA, FERENC: Magyarok és a franekeri egyetemi oktatás. Debrecentől Amszterdamig. Magyarország és Németalföld kapcsolata a kora újkorban. Szerk. PUSZTAI GÁBOR, BOZZAY RÉKA. Debrecen, 2010. 115.

${ }^{82}$ Szilágyi Tönkő Mártont 1699. szeptember 27-én. SZINNYEI JÓZSEF: Magyar írók élete és munkái. online kiadás: http://mek.niif.hu/03600/03630/html/sz/sz26642.htm (hozzáférés dátuma: 2012. december 1.)

${ }^{83}$ A tanárok életrajzát lásd: A Debreceni Református Kollégium története. Szerk. BARCZA JózSEF. Debrecen, 1988. vonatkozó fejezeteit.

${ }^{84}$ Csernákról bővebben: BozZAY RÉKA: László Csernák (1740-1816) een Hongaarse hoogleraar in Deventer. Lage Landen, Hoge Heuvels: Handelingen Regionaal Colloquium Neerlandicum. Szerk. NOVAKOVIĆ-LopUŠINA, JELICA-BritKA, TAMARA-BUDIMIR, BojanA-VuKomanović, LADA-CVETKOVIĆ, MiRKo. Belgrád. 2012. 425-433. 
észak-németalföldi egyetemek, elsősorban az utrechti, jelentős anyagi támogatást nyújtottak egyetemi tanulmányaikhoz. Itthon megszerzett ismereteiket volt iskolájuk, egyházuk vagy városuk szolgálatába állították. 